\title{
Practicing New Economic Geographies: A Methodological Examination
}

\author{
Henry Wai-chung Yeung \\ Department of Geography, National University of Singapore
}

\begin{abstract}
Practicing new economic geographies necessarily entails a critical re-evaluation of research methodologies because of its different substantive research foci. In this article, I examine some methodological implications of the recent refiguring of the "economic" in economic geography. Some key features of new economic geographies include understanding the social embeddedness of economic action, mapping shifting identities of social actors, and exploring the role of material and discursive contexts in shaping economic behavior. I argue that practitioners of new economic geographies can no longer rely exclusively on established "scientific" methodology for empirical research and data analysis. Instead, I argue for a process-based methodological framework through which we employ complementary methodological practices (e.g., tracing actor networks and in situ research) and triangulation, not only to explore the microfoundations of economic action, but also to generate, in a reflexive manner, theoretical insights from the multiscalar dimensions of economic action. Keywords: actor networks, new economic geographies, process-based methodological framework, research practices, triangulation.
\end{abstract}

$\mathrm{S}$ ince the late 1980s and the early 1990s, theoretical and empirical advances in economic geography have increasingly reshaped the nature of the subdiscipline and connected it to wider discourses within the social sciences. In particular, the concept of "economic" has been refigured such that it is no longer seen as singular, unidimensional, deterministic, and aspatial. Indeed, Thrift and Olds $(1996,313)$ argue that we need to "make a space for new kinds of economic geography that can supplement or even replace the older forms of economic geography." In this process of broadening the discipline of economic geography, we must appreciate how to "contextualize rather than to undermine the economic, by locating it within the cultural, social, and political relations through which it takes on meaning and direction" (Wills and Lee 1997, xvii). Several progress reports and literature reviews have detailed how these exciting developments since the late 1980s_collectively known as "new economic geographies" 1 in this article-have transcended the normal intellectual orbit of economic geography and influenced empirical research in corporate geography (Yeung 1994, 2001b; McDowell 1997; Schoenberger 1997), political economy (Barnes 1995, 1998b; Scott 2000), the geography of finance (Leyshon 1998; Amin and Thrift 2000), and the geography of consumption (Crewe 2000; Jackson 2002). New economic geographers are engaging in an intellectual project that, according to Barnes $(1996,49)$, "abandons any notion of progress, accepts that subjects are made and not given, avoids a homogenizing and totalizing portrayal of the world, and discards any essentialist notions of knowledge."
Despite this recent interest created by the promise of new economic geographies, however, we seem to have missed a crucial point-the methodological issue. The practicalities of what it means to "do" new economic geographies are still unclear and remain underdeveloped. Recent philosophical debates in economic geography have mostly focused on why we need to refigure the "economic" and to broaden it to include other social, cultural, and institutional considerations. Still others have practiced these new economic geographies without explicitly considering their methodological implications. It is clear that practicing new economic geographies requires a critical reevaluation of research methodologies that goes beyond simply the choice of research instruments per se (e.g., sample surveys versus personal interviews) to include the entire process of practicing research itself. ${ }^{2}$

This article aims to examine the methodological implications of the recent refiguring of the "economic" in economic geography and, on the basis of these implications, to develop a process-based methodological framework for understanding the practice of new economic geographies. This process-based methodological framework is defined as the creative and coherent deployment of different methodological practices as different "moments" 3 of a research process that is sensitive to specific research questions and/or contexts. The framework is process-based because the configuration of different methodological practices is driven by the research process itself, rather than some preordained philosophical positions. It is certainly not just about a methodological framework for examining economic-geographical 
processes. "Methodology" refers to the entire process of practicing research (e.g., positivistic and interpretive methodology) and methods as specific technique and/or instruments for research (e.g., sample surveys and indepth interviews). My purpose here is neither to construct a new methodology for new economic geographies nor to write a methodological "cookbook" on how to practice new economic geographies. My focus on linking substantive research issues and their methodological implications also precludes the mapping of the complex interrelationships between epistemologies (e.g., spatial science, critical realism, feminism, and poststructuralism) and research methods, which are better addressed elsewhere (e.g., Jones and Hanham 1995; Staeheli and Lawson 1995; McKendrick 1999; Del Casino et al. 2000). My basic premise is that new economic geographers are not only asking different substantive questions from their predecessors (e.g., neoclassical economic geography in the 1970s and the 1980s), but also thinking differently of explanatory variables or what count as geographical explanations of economic and social action. This different orientation in geographical explanations justifies a fundamental rethinking of the process of research methodology, because we might be looking at different subject/object relations, and different ways of collecting, analyzing, and even presenting data.

While I empathize with the epistemological aim of some new economic geographers to move away from integrated entities and their supposition of commonalities, my search for a process-based methodological framework can be justified on several grounds. First, without fully understanding their methodological implications, new economic geographies may be nothing more than "an exclusionary cultural essentialism in the 'new'" (Martin and Sunley 2001, 152) that privileges an oversocialized epistemology and a less-than-rigorous methodological framework. An unfortunate outcome might be that new economic geographers find it difficult to communicate with, let alone convince, their counterparts elsewhere in human geography and allied disciplines in the social sciences. Second, new economic geographers are clearly as much concerned with substantive research issues as with the reflexivity that underscores their research process and outcomes. A process-based methodological framework ensures that such reflexivity can be intersubjectively understood and shared when new economic geographers evaluate research outcomes of other fellow geographers.

Third, the concern with different substantive issues implies that new economic geographies can no longer rely exclusively on established "scientific" methodology for empirical research (e.g., collection of large-scale datasets through surveys and field measurements) and data analysis (e.g., modeling, hypothesis-testing, and quantitative content analysis). Widely accepted and practiced in neoclassical economics and by its followers in certain branches of economic geography and regional science (see Barnes 2001a), this methodology has often been perceived as "scientific" and "objective" in that it is "neutral" in research execution and it separates the researcher from the subject researched. As Pile $(1991,467)$ observes, "[G] eographers have acted as if they stand outside the specific historicity and geographicity of their subjects; this has enabled them to comment on the reality of the subject's view of their own situation, while not allowing the subject's equally valid versions of reality" (see also Dixon and Jones 1996; Jones, Nast, and Roberts 1997; Sayer and Storper 1997). This quest for the so-called scientific method, in fact, has obfuscated the real issue of whether the empirical world in which we live is knowable and observable. As argued by Clark (1998b, 74), "[A]cademic objectivity, in a strong sense, is only plausible if we retreat to a theory of knowledge that idealizes facts and strips bare the complexity of [social] life."

Using the above "scientific" methodology as the backdrop in this article, I develop a process-based methodological framework through which we employ complementary methodological practices and triangulation, not only to explore the microfoundations of economic action, but also to think carefully about how to generate theoretical insights from the multiscalar and contingent nature of economic action and social behavior. ${ }^{4}$ Instead of focusing my discussion too narrowly on the nuts and bolts of research methods, I demonstrate how different research practices can be brought together within this process-based methodological framework legitimized by its "tripartite litmus test"—validity, reliability, and reflexivity. I do not pretend that this framework is eclectic and fitting in all research contexts and circumstances. Instead, the use of triangulation in this framework is based on the conviction that "[T] here is no fundamental clash between the purposes and capacities of qualitative and quantitative methods or data. What clash there is concerns the primacy of emphasis on verification or generation of theory" (Glaser and Strauss 1967, 17). While Clark's (1998b) recent article has usefully discussed the different methodological implications of "stylized facts" and "close dialogue," I expand on his arguments and consider, in my framework: (1) the use of secondary and quantitative data, (2) the need to trace actor networks, (3) the role of in situ research, and (4) the use of deconstruction/abstraction to build grounded theories. Taken together, these methodological practices constitute different moments of my process-based methodological 
framework that can contribute to refining the methodology for practicing new economic geographies.

The article is organized into three major sections. The next section outlines very briefly three substantive issues in the study of new economic geographies. The following section examines various methodological implications of practicing new economic geographies and situates these implications within the constitutive moments of the process-based methodological framework. These methodological implications are then followed up in the penultimate section, which develops, on the basis of triangulation, an understanding of the advantages associated with the process-based methodological framework. The concluding section discusses the policy and ethics issues in relation to my framework.

\section{What's "New" in the Study of New Economic Geographies?}

There is no doubt that new economic geographers have advanced the frontiers of geographical research to incorporate substantive issues traditionally considered to be outside mainstream economic geography (see a recent intervention by Amin and Thrift 2000 and expanded responses in Peck and Wills 2001). At the very least, new economic geographers have refigured the "economic" through an excursion into the "cultural," the "institutional," and the "political." As Barnes $(1999,17)$ notes, the basic explanatory categories become "social power, cultural identity, and institutional situatedness rather than economic ownership, universal definitions, and individual agency." It is not my intention to review comprehensively what constitute new economic geographies (see Barnes 1996; Lee and Wills 1997; Sheppard and Barnes 2000) or the "cultural turn" (see Barnett 1998; Barnes 2001b; Jackson 2002), for drawing such boundaries and categorizing their concomitant substantive issues is futile. Instead, I intend to present only some of its key features to inform my methodological examination in the following sections. These features include understanding the social embeddedness of economic action, mapping shifting identities of economic actors, and exploring the role of context in explaining economic behavior. While I am aware that this stylized presentation may fall into some kind of essentialism or normative construct, my defense is that we need to identify at least some key features of new economic geographies before we are able to address their methodological implications in a meaningful way and to link these implications to the proposed process-based methodological framework. Moreover, the aim of this article is to create and engage in dialogues, rather than to define the final vocabulary of what constitutes new economic geographies and how geographers should go about practicing them (see also Yeung 2001a, 2002a).

Beginning with Polanyi's (1944) seminal work and its reconstruction by Granovetter (1985), the concept of embeddedness has made a significant impact on what Granovetter and Swedberg (1992) call the "new economic sociology." The concept poses a serious challenge to the "undersocialized" view of economic action typically found in neoclassical economics. In its simplest sense, embeddedness refers to the argument that "[T]he [economic] behavior and institutions to be analyzed are so constrained by ongoing social relations that to construe them as independent is a grievous misunderstanding" (Granovetter 1985, 482). Dicken and Thrift (1992) subsequently introduced the concept to economic geography, and a large body of research in new economic geographies has since examined the sociospatial embeddedness of economic action in industrial firms and their business networks. These studies range from debates on geographical agglomerations, industrial districts, and regional development to empirical investigations into social divisions of labor and local labor markets, changing production methods, and the spatial transfer of manufacturing technologies (see my reviews in Yeung 1994, 2000b, 2001b). What these studies have plainly shown is that economic institutions-for example, firms and marketsare embedded in wider social relations such that they are spatially bound by these relations in their locational and labor strategies, as well as constrained by the influence of proximity in their innovative activities. Understanding the economic geographies of firms and labor systems requires more than an analysis of economic and locational factors, the primary analytical focus of neoclassical economic geography up to the late 1970s. More importantly, new economic geographers begin to examine the complex ways through which these economic institutions are spatially entangled in webs of socialized and institutionalized relationships. As such, these economic institutions are not conceptualized merely as economic machines responding to external market and cost conditions. Equally important, they are also seen as organizational constellations of social relations among individual actors "whose action is both facilitated and constrained by the structure and resources available in the social networks in which they are embedded" (Granovetter 1991, 78).

How, then, do these social actors generate and perform economic action over time and space? This question brings us to the second key feature of new economic geographies-how the shifting identities of these economic actors are spatially and discursively differentiated by 
gender, ethnicity, class, and culture. This line of geographical enquiry fundamentally argues that representational plurality and multiplicity helps to explain diverse economic activities among social actors. Instead of conceptualizing economic units (e.g., the firm and the labor market) as a singular site of rational, reproductive, and progressive imperatives, new economic geographers have been concerned with "de-centering" and "destabilizing" these fundamental categories of organizing social life because "[I]dentities are viewed as contingently constructed through differentiated systems of power whose operation is never neatly contained within or outside the boundary of the category" (Dixon and Jones 1998, 255). Thrift and Olds $(1996,319)$ declare that "[T] he very idea of a singular story of an object denoted 'economic' is now lost. It follows that the idea of trying to focus a new economic geography around one concept or theoretical tradition, however broadly defined, cannot hold." Similarly, Gibson-Graham (1996, 15-16) argues that " $[\mathrm{A}]$ capitalist site (a firm, industry, or economy) or a capitalist practice (exploitation of wage labor, distribution of surplus value) cannot appear as the concrete embodiment of an abstract capitalist essence. It has no invariant 'inside' but is constituted by its continually changing and contradictory 'outsides"' (see also Walters 1999). Economic actors are argued to be embedded in social discourses and practices, and therefore they cannot be conceived as rational and mechanistic economic entities, as in neoclassical rational-choice theory.

Recent work by Schoenberger (1998) and others (Thrift 1998, 1999a; O'Neill and Gibson-Graham 1999; O'Neill 2001; Hanson et al. 2002) has shown that the behavior of corporate firms and economic actors is by no means governed by a singular logic of profit maximization. Rather, these actors are subject to multiple discursive practices governed by power relations and influenced by the actors' gender, ethnicity, and culture. For example, in the corporate world, managers are no longer able to understand and grapple with rapid changes and transformations, as the global economy becomes increasingly complex and uncertain. As such, Thrift (2000b, 674) argues that "[F]irms now live in a permanent stage of emergency, always bordering on the edge of chaos." Managers increasingly rely on an emerging new form of reflexive business knowledge encapsulated in the idea of ongoing practice and performance. This refiguring of the "economic" has important implications for discursive practices and politics. O'Neill and Gibson-Graham (1999, 11), for example, view the disruptive representation of the firm as "opening up political options for action in place and over space that are relatively invisible in the vicinity of a stable, coherent, and self-reproducing firm."
This concern with the "open" and contingent nature of economic systems leads me to the third key feature of new economic geographies: the role of context in shaping and understanding economic behavior in time and space. To de-center such theoretical categories as the "economic," new economic geographers have consciously argued against logical determinism in positivism and structural determinism in Marxism. As mentioned above, the multiplicity of economic action and behavior points to the impossibility of predetermining economic outcomes, historically and spatially. Instead, the context in which this multiplicity of identities and logics shapes the social practices of economic actors constitutes the key starting point in most recent studies of new economic geographies. Context is important for new economic geographies simply because it is integral, not external, to the subjects/objects under investigation. This internalized view of context differs significantly from the external interpretation of context in neoclassical economic geography and its subsequent variants (see Barnes 1996, 2001b; Sunley 1996; Barnett 1999). If one accepts that economic action takes place contingently within a sociospatial world, there is no reason why this action can be ontologically separated from the same world as a separate category for description and analysis. In other words, context sets the contingent conditions in which economic action can be realized and analyzed.

This contingent property of context, however, differentiates it from the first two key features of new economic geographies. Embeddedness and identities are clearly about more than the importance of context; they areimplicitly, at least, and sometimes explicitly_posed as necessary relations to the economic action under investigation. Thus, the context of economic action becomes a critical component in any economicgeographical explanation. As the discursive plurality of social actors increasingly shapes this context, it is highly difficult to determine the exact causality of economic action. The methodological challenge of understanding context in practicing new economic geographies thus becomes immense.

\section{Beyond Stylized Facts and Close Dialogue: Methodological Implications of Practicing New Economic Geographies}

Clark's (1998b) recent article in this journal has made a crucial distinction in relation to the methods of studying economic geography in economics and in geography. $\mathrm{He}$ observes that whereas stylized facts tend to be preferred by mainstream economists concerned with economic 
geography and increasing returns to scale (via spatial agglomeration), economic geographers tend to engage in close dialogue with the subjects under research. Taking a philosophical skepticism perspective, he (1998b, 78) claims that both methods are "part and parcel of an inevitable and never-ending test of claims in the construction of social knowledge." His preference seems to elide with close dialogue as "a means of reintroducing geography (and history, sociology, etc.) into a world that seems to have been made up for the benefit of theorists" (Clark 1998b, 82). Clark's methodological article has thus provided some useful philosophical justifications for one particular research instrument - that is, close dialogue-in practicing research in economic geography. Primarily because of his concern with contrasting the methods of studying economic geography in economics and in geography, Clark (1998b, 74) seems less interested in evaluating the links between substantive research issues in economic geography and their concomitant research methodologies.

My article takes its point of departure from where Clark has left off, building upon his arguments for "reaping progressive benefits" from the use of close dialogue in economic geography. I am therefore not reacting against Clark's proposal for close dialogue. Rather, I argue that practicing new economic geographies requires us to take a step back from both stylized facts and close dialogue, and to adopt a process-based methodological framework to better understand the complexity of economic life.

Before I consider different moments of this processbased methodological framework, I want to introduce my methodological "litmus test," which I shall revisit in each of the following subsections. In practice, my proposed framework can be justified on three criteria: validity, reliability, and reflexivity. The origins and rationales of the first two criteria are fairly well known in standard socialscience research methodology and will not be examined in detail here. As argued by Silverman (1993, 156), "[T]he issue of validity is appropriate whatever one's theoretical orientation and use of quantitative or qualitative data." In its simplest terms, "validity" refers to whether the research process and instruments used are approximating the correct phenomenon and whether they explain what they set out to explain. "Reliability" simply refers to the replicability of findings. "Reflexivity" can be defined as the capacity of the research practice to allow the researcher to reflect upon his/her own situatedness in the research process. These situated reflections involve the worldview underpinning such research, the conditions under which the research is conducted, and the conditionality that leads certain (but not other) findings to be known and/or knowable. This third criterion is particularly relevant to my methodological examination of practicing new economic geographies, not least because it has hardly been adopted in evaluating research in neoclassical economic geography. More importantly, the relevance of reflexivity is heightened by the normative concern of new economic geographies with actor emancipation and immanent critique.

To support my arguments further, I need to raise another methodological point: there may not be a simple one-to-one direct correspondence between epistemology and research practices in economic geography. This noncorrespondence problem results from different empirical situations that cannot be prespecified in advance of the research process. It also explains my reluctance to match different epistemological divisions in economic geography directly with specific research methods. First, different epistemological divisions in economic geography originate from selective geographers' excursions into philosophical debates. These debates in the philosophy of social science tend to be exclusively concerned with ontology and epistemology, and to leave the theoretical and methodological work to each substantive social science (see Sayer 1992 and Yeung 1997b on critical realism; Jones, Nast, and Roberts 1997 for feminism). The setting up of a distinct methodological apparatus is therefore the responsibility of individual disciplines (e.g., ethnography and fieldwork for anthropology and geography, experimental laboratories for psychology). It is possible that the same epistemology will result in different research methods (e.g., analytical abstractions and quantitative analysis in Marxism). Second, the purposes and exact practical circumstances of the research process may significantly shape the choice of methodological practices. For example, Hammersley $(1992,51)$ argues that the "selection among these positions [quantitative vs. qualitative] ought often to depend on the purposes and circumstances of the research, rather than being derived from methodological or philosophical commitments." In an actual research process, we often adapt and adjust our methodological practices in view of changing research contexts. In this sense, we may have a perfectly valid and reliable research design in theory-say, a postal survey to find out about the employment practices of automobile firms in one specific locality. In practice, however, we may face serious social and cultural resistance to a postal survey in the local community. This practical difficulty may not only jeopardize our field research, but also render our methodological practice invalid and unreliable. Different methodological practices are thus appropriate in different epistemological and research contexts (see Layder 1993; Baxter and Eyles 1997; McKendrick 1999; Del Casino et al. 2000). 
Table 1. Assessing the Validity, Reliability, and Reflexivity of Research Practices in Economic Geography

\begin{tabular}{|c|c|c|c|c|c|c|}
\hline \multirow[b]{2}{*}{ Research Practices } & \multicolumn{2}{|c|}{ Validity in Explanation } & \multicolumn{2}{|c|}{ Reliability of Data } & \multicolumn{2}{|c|}{ Reflexivity of Approach } \\
\hline & $\begin{array}{c}\text { Neoclassical } \\
\text { Economic } \\
\text { Geography }\end{array}$ & $\begin{array}{c}\text { New } \\
\text { Economic } \\
\text { Geographies }\end{array}$ & $\begin{array}{c}\text { Neoclassical } \\
\text { Economic } \\
\text { Geography }\end{array}$ & $\begin{array}{c}\text { New } \\
\text { Economic } \\
\text { Geographies }\end{array}$ & $\begin{array}{c}\text { Neoclassical } \\
\text { Economic } \\
\text { Geography }\end{array}$ & $\begin{array}{c}\text { New } \\
\text { Economic } \\
\text { Geographies }\end{array}$ \\
\hline $\begin{array}{l}\text { Using quantitative and } \\
\text { secondary data }\end{array}$ & Strong & Weak & Strong & Ambiguous & Irrelevant & Weak \\
\hline Abstraction/deconstruction & Irrelevant & Strong & Irrelevant & Good & Irrelevant & Strong \\
\hline
\end{tabular}

The following subsections aim to examine the validity, reliability, and reflexivity of different methodological practices and their robustness in new economic geographies, using standard "scientific" methodology in neoclassical economic geography as the template for comparison and contrast. In particular, I consider: (1) the use of primary and secondary quantitative data, (2) the need to trace chains and networks, (3) the role of in situ research, and (4) the use of deconstruction and/or abstraction to generate theoretical insights. These are all interrelated moments of the process-based methodological framework for practicing new economic geographies. This section relates these moments of the framework to the three substantive issues reviewed in the previous section; the next section offers a full justification for the framework. In Table 1, I summarize the assessment of different research practices in two contrasting variants of economic geography on the basis of their validity, reliability, and reflexivity. It should be noted that these three criteria are neither always necessary nor relevant to my assessment of a particular research practice, because their necessity and/or relevance depends on research objectives and the kinds of empirical questions. Their degrees of strength and relevance may also vary in relation to different research objectives and substantive questions. In some research instances (e.g., tracing actor networks), a more reflexive research practice may lead to ambiguous reliability.

\section{Primary and Secondary Quantitative Data}

Choosing the right kind of data required is perhaps the most crucial moment in any methodological framework. Much of neoclassical economic geography originates from what Barnes (2001b, 546) terms "epistemological theorizing," which assumes "that spatial economic phenomena could be expressed in an explicitly abstract, formal, and rationalist vocabulary and directly connected to the empirical world." It has been concerned with explaining the logic behind the spatial patterns and processes of economic activities. This approach is underpinned by a quantitative methodology which, to borrow from Philo (1998a), was and still is about "the things that count." ${ }^{6}$ Large quantitative datasets about individuals and firms are collected through direct surveys (primary data) or surveys by government and nongovernment agencies (secondary data). Data about firms and regions can also be collected through transactional records and other cumulative means of data bookkeeping. These data are processed through inferential statistics to test the statistical significance of predefined hypotheses and/or models. Valid findings are then generalized into theories and laws for predictive-and in some instances social engineering - purposes. As the researcher is quite isolated from the researched, this process is deemed highly neutral and objective, and is therefore awarded the esteemed status of being "scientific." The fundamental assumption of this positivist methodology is that the economic system under observation is "closed" and economic processes are empirically observable. A "closed" economic system implies that the causality of empirically observable outcomes can be identified and measured, and no external influence on this causality can be found. This methodology seems to achieve strong reliability, because repeated observations of causality can be made and should generate the same results (see Table 1). It is also deemed valid because the research instrument (e.g., survey) can measure what it is supposed to measure (e.g., employment characteristics). Quantitative methods and data, however, are much less concerned with reflexivity, to the extent that it is regarded by most neoclassical economic geographers as irrelevant to their practice of modeling the geographical world constituted by measurable objects rather than social actors.

If economic systems are much more open and subject to multiple codetermination by different social actors, as is argued in new economic geographies, the reliance on primary or secondary quantitative data becomes questionable (see Table 1). One begins to question both the weak validity and the weak reflexivity of using these 
quantitative data to explain economic behavior of social actors. Since quantitative data are not sensitive to variations in experiences at the individual social actor level, they are not necessarily valid measurement of the rationale and behavior of these social actors. If we take the economic action of these actors as socially embedded and highly contextualized, the validity of quantitative data is even more questionable, since indicators of economic action may not be compatible with the goal of measuring social and cultural behavior. Even though some actor behavior can be codified and quantified via behavioral models and/or psychological tests, these quantitative data are still unable to capture adequately differential experiences and contexts associated with actor behavior. For example, some studies in new economic geographies have not found validity in quantifying the pluralistic identities of gender and ethnic relations (McDowell 1992; Lawson 1995; Yeung 1997a). Quantitative data, whether in their primary or secondary genres, are neither necessary nor always appropriate in generating valid and reflexive explanations of social actors in new economic geographies.

That does not mean, however, that quantitative data are useless for new economic geographies. I am therefore skeptical of Philo's (1998a, 191) observation that "[I]t remains the case that clear lines of demarcation are today still widely recognised as separating quantitative geographers who count, calibrate, map, and model the thingworld from qualitative geographers who converse, consort, engage, and empathise with the people-world" (emphasis in original). I wonder whether we really have to divide the world into the "thing-world" and the "people-world." If new economic geographies is concerned with actors and their "people-world," does it then mean that these geographies (and their geographers) cannot be interested in the "thing-world" in which these actor geographies are embedded and mediated? Why can actors and their "people-world" not be counted and analyzed? Similarly, why can physical things and their complex spatial relations not be conceptualized, engaged, and empathized? In fact, using an appropriate method of analysis (e.g., the expansion method; see Casetti 1972), quantitative data might be more valid in describing carefully contextualized relations of social actors and in explaining the spatial behavior of such actors at higher levels of abstraction-say, firms, industries, and regions (see Jones and Hanham 1995; Plummer, Sheppard, and Haining 1998; Plummer and Sheppard 2001; Plummer and Taylor 2001; Sheppard 2001).

But what about the reliability of these quantitative data? Surely they are much more reliable than alternative data (e.g., close dialogue, oral histories, ethnographic notes, and so on). I argue that while quantitative data retain some degree of reliability in the study of new economic geographies, they are not necessarily more reliable than other forms of data. There are two reasons for this ambiguous necessity of quantitative data for new economic geographies (see Table 1). First, the changing empirical and research contexts may undermine the reliability of quantitative data. Since new economic geographies privilege an integral contextual approach to interpreting data, quantitative data may be exposed to the problem of "reified contexts," in which the context of economic behavior by social actors may be categorized as a stand-alone variable. This process of stripping context into an independent variable is guilty of methodological reductionism, and the richness and contingency of context in shaping economic behavior are lost. In terms of the research context, the reliability of quantitative data may be compromised by the power structure of knowledge creation. As Clark (1998b) acknowledges, some respondents are more cooperative in providing answers to certain kinds of interviewers who might have legitimate claims to these data (i.e., the "interviewer's effect"). Other researchers from much lower power strata may find it difficult to replicate the same set of quantitative data, for both cost and status reasons (see also Schoenberger 1991; Cochrane 1998; Herod 1999; Sabot 1999).

Second, other forms of data obtained beyond stylized facts and close dialogue may be as reliable as quantitative data. New economic geographers study not only the nexus between the economic and other spheres of social life, but also the discursive context in which knowledge of this nexus is created. In other words, the spatial effects of discourses and power relations embedded in a dominant form of capitalism can be among the substantive issues in new economic geographies (e.g., Clark and Wojcik 2001; Kelly 2001; Bunnell 2002; Coe and Kelly 2002). This line of inquiry requires genealogical research that "becomes the reconstruction of trajectories of discourses and practices which produced a unified capitalism" (Walters 1999, 321). Much of the data for genealogical research and the related discourse analysis originate from key writers, proponents, politicians, and other advocates of a particular hegemonic discourse. Information about the power structure of knowledge creation and reproduction-that is, the situatedness of knowledge and the researcher's reflexivity-is also necessary in this project (Pile 1991; Keith 1992; Thrift 1996; Rose 1997; Cochrane 1998; Hammersley 1999). All these data and information may be reliably obtained from existing intellectual and popular publications, public speeches, and policy statements. Even the Internet and abstract databases may be a useful source of data for discourse analysis in new 
economic geographies (see Pritchard 1999; Chapman and Edmond 2001). These kinds of data may be "unconventional" in much of economic geography, but they may enable new economic geographers to be more reflexive, and they promise to unravel the underlying power structures and social relations in the (re)production of our geographical knowledge.

\section{Tracing Actor Networks: Unpacking Heterogeneous Power Geometries}

Insofar as we have de-centered the alleged methodological robustness of data obtained through quantitative surveys and measurements, we are now able to proceed with another major methodological challenge to practicing new economic geographies - the existence of multiple and overlapping actor networks that generate heterogeneous associations and relations among social actors. Two clarifications are needed here: why actor networks are important for new economic geographies, and what the relations are between new economic geographies and actor-network theory.

Since this article is primarily a methodological contribution, I shall be brief in clarifying the first issue. Actor networks are an important focus for research in new economic geographies because all kinds of networks are constituted by these heterogeneous associations and relations among actors. Actor networks range from personal/social networks and organizational networks to interfirm networks and business networks. For example, insights from the above review of the literature show that even such a crucial analytical category as "the firm" can no longer be conceived as a "black box" stabilized by purely economic transactions (see also Yeung 2000c, 2002d; Dicken and Malmberg 2001; Taylor and Asheim 2001). Instead, business firms are constituted by all sorts of heterogeneous relations among actors from different divisions, customers, suppliers, and other organizations.

Clarifying the second issue may take a full article in its own right, connecting new economic geographies to actornetwork theory. ${ }^{7}$ But again I shall be brief here too by stating categorically that actor-network theory has recently received sympathy from only some quarters of new economic geographies. In this article, actor-network theory is taken as a theory of the sociology of (scientific) knowledge and practices; it is certainly not a straightforward network analysis. While I accept rather uncritically the conceptual apparatus of the theory, as evidenced by my use of familiar terms in the theory, my intention in this article is to examine the methodological implications of researching into actor networks. This methodological analysis of actor networks is necessary, regardless of whether one accepts the epistemological claims of actornetwork theory (see my explanation above of the "noncorrespondence problem").

In methodological terms, actor networks are simply opaque to existing analysis in neoclassical economic geography, because their heterogeneous actor relations and association may not be empirically observable and distinguishable from other social and economic patterns. As shown in Table 1, the validity of tracing these actor networks becomes questionable in neoclassical economic geography because of major measurement problems. The research practice is also perceived as highly unreliable because of its ad hoc and unpredictable nature. These methodological problems explain why actor networks find no place in neoclassical economic geography. Even quantitative network analysis (e.g., in sociology) does not go beyond mathematical modeling and/ or statistical manipulations of empirically measurable variables of actor points and locations. New economic geographers, however, afford much more validity and reflexivity to tracing networks, as a key research practice for understanding the territorial constitution and reshaping of economic organizations via their engagement with an array of actor networks. This stance reflects the methodological commitment to the "reconstruction of power without refiguring it as an inhuman force leading to foregone conclusions" (Thrift, Driver, and Livingstone $1995,1)$. It also necessitates intimate knowledge of these social actors and their intermediaries through close dialogue and other ethnographic methods (see Miller et al. 1998 for an exemplary study of geographies of consumption).

Nevertheless, tracing actor networks is a risky and difficult endeavor. Its reliability is still open to question, primarily because the power geometries of these actor networks are constantly shifting and reconfigured (see Table 1). Parry $(1998,2149)$ coins the term "hybrid networks" to describe these shifting actor networks. Tracing actor networks is therefore not as simple a method as implied by Murdoch $(1997,332)$, who states that:

Network analysis is quite simple: it means following networks all the way along their length; there is no need to step outside the networks for all the qualities of spatial construction and configuration of interest will be found therein ... Actornetwork theorists thus reject the view that social life is arranged into levels or tiers some of which determine what goes on in others; everything is kept at "ground level."

But then, does not keeping things at "ground level" lose sight of the structural power relations within the global economy? It may be true that "capitalism" is too abstract a 
category to be very useful in understanding the spatial specificity in the global economy or the finer empirical contexts of economic life (necessarily incorporating the noneconomic). However, we should surely not discard this level of abstraction entirely. To constrain our analyses of the "economic" to the "ground level" and to approach the power relations therein as simply traceable through tangible linkages would be a mistake (see more in Yeung 1998a, 2000a, 2002c; Dicken et al. 2001; Henderson et al. 2002).

The objective of tracing actor networks in new economic geographies is not to produce highly replicable results; the primary concern is with its methodological validity and reflexivity (see Table 1). This methodological focus follows from an ontological conception of heterogeneous networks as relations and its epistemological implications for open-endedness in geographical theorization. As noted by Thrift (1999b, 57), the purpose of understanding actor networks is about "emphasizing the contingency of the world and the many possibilities that are open at any point." Thus, a fundamental methodological requirement of tracing actor networks should be to acknowledge three critical dimensions of these networks: (1) the autonomous power of actors; (2) the role of intermediaries; and (3) the interconnections of nodes. First, it is important not only to recognize the autonomous power of social actors, but also to prioritize power relations in their heterogeneous association. Through this practice of prioritization, we may be able to pinpoint the key actors in a particular network and to trace how the heterogeneous power relations in this network are spatially constituted and realized (cf. Parry 1998; Ward and Jones 1999). The identification of key actors requires intimate knowledge of the network through intensive research methods (e.g., participant observations, focus groups, close dialogue, ethnography, and action research). In other words, the researcher has to immerse in, and be enrolled into, the network. The researcher and the researched may not be clearly distinguishable, and this procedure often increases the degree of reflexivity experienced by the researcher (see Herod 1999; Kitchin and Hubbard 1999). Akin to ethnography in anthropology, this methodological practice contrasts sharply with the idea of an "objective" researcher in the scientific approach to neoclassical economic geography. As argued above, however, this latter scientific approach to studying networks from the outside does not seem to have any more validity and reliability (and likely has less reflexivity) than the tracing approach suggested hereafter.

Second, the role of intermediaries can be critical in our understanding of the material and spatial constitution of actor networks. After identifying key actors in networks (e.g., an entrepreneur), it is also necessary to identify specific intermediaries that can be human (e.g., an accountant) and nonhuman beings (e.g., institutionalized business norms and rules). These intermediaries provide the social and institutional foundation upon which spaces of actor networks are prescribed and negotiated (see Murdoch 1999). The validity and reflexivity of tracing actor networks can be substantially enhanced if the researcher is able to link these intermediaries to their key actors and to demonstrate the mechanisms through which power geometries are configured and executed. Network intermediaries play a facilitating role in keeping actors together and materializing their power. How, then, should the researcher best identify these intermediaries in actor networks? This question of reliability of data on a particular network and its actors can be satisfactorily answered once the researcher is able to become immersed in the networks. This is because actor networks encapsulate the totality of actors' intentions, behavior, and action.

The third—and perhaps most important—dimension of tracing actor networks is to acknowledge the interconnections of nodes in these networks. Since heterogeneous associations of actors in networks almost necessarily create disorders and ambiguities, it is methodologically important to make sense of these networks by determining the interconnections of their nodes, which may be occupied by actors, intermediaries, or others. Through these nodes, actors control and exercise power relations "from a distance." To borrow from Castells (1996), for example, nodes in global spaces of flows have particular spatial characteristics. They may be embodied and located in global cities, which provide the wider social and economic fabric for the performative acts of these actor networks. In methodological terms, we need to trace the interconnections of these nodes in specific actor networks (e.g., intercity material and nonmaterial flows). We also need to build connections between these nodes and actors and their intermediaries (e.g., the residence of key actors and/or their intermediaries in global cities). To a certain extent, this research can be fruitfully conducted via established methods of data collection and analysis (e.g., in urban studies; see Beaverstock, Smith, and Taylor 2000). But a significant portion of this analysis must still be conducted through tracing networks, because some of these nodal interconnections may be impervious to direct measurement and empirical observations (e.g., multiple and transnational residence of key actors). Taken as a whole, tracing actor networks may be a potentially powerful methodological practice through which to unravel the complexity of economic geographies and, for that matter, social life. 


\section{In Situ Research: Understanding Context and Identities}

A related methodological implication of tracing actor networks is that much of the research has to be conducted in situ. This spatial constraint on practicing new economic geographies is not entirely new at all. In situ research has always been hailed as the vanguard of ethnographic research in anthropology, to provide what Geertz (1973) terms "thick" descriptions of people, culture, and society (see also Keith 1992). In this article, the demand for in situ research is viewed as one of the key methodological dividing lines between neoclassical economic geographers and new economic geographers. Whereas the former tend to rely on stylized facts and modeling to approximate the real world, the latter appreciate and unravel the complexity of economic landscapes through direct and intimate research into the firms, industries, and markets concerned. While Clark (1998b) has already explained the origins and choreography of these two different methodological traditions, it remains to be seen why in situ research provides a better understanding of issues confronting new economic geographies. In neoclassical economic geography, in situ research is not necessarily viewed as more valid and reliable, because large-scale quantitative data can be collected via various methods that, in turn, can be organized and controlled in one particular location (see Table 1). Since neoclassical economic geography is concerned with empirically measurable phenomena, there is no urgency for its practitioners to engage in field research in situ. Interestingly, in situ research seems to have more significantly influenced the methodology of physical and environmental geography.

The role of in situ research, however, takes on a very different meaning in the methodology of new economic geographies, which seeks to understand the material and discursive constructions of actor identities and voices. ${ }^{8}$ For example, Schoenberger's $(1994,1997)$ study of Lockheed and Xerox examined the role of identity and knowledge of key executives in shaping corporate strategies, which in turn lead to the rise and fall of corporations. Similarly, O'Neill and Gibson-Graham's (1999) recent study used excerpts from interviews with managers of an Australian-based multinational to deconstruct the dominant monopoly capitalist representation of the company. The methodological implications of practicing new economic geographies are clear. One may argue that these firms should always have a dominant "voice" and representation that legitimizes stylized modeling of the firm as a coherent whole. Both cited studies show, however, that our monolithic conception of the "firm" has to be revised. The firm is indeed a messy constellation of multiple identities, contestation of power, and shifting representations (see also Yeung 2000c, 2001b, 2002d). To write off this multiplicity and contestation as "distortions" of the overall picture of the "representative firm" is a gross mistake in much of neoclassical economic geography, in which there is a clear division between the firm as the object of research and the researcher as an external observer. Similar to the role of laboratories in the physical sciences, the firm is akin to an experiment through which an economic geographer observes its dynamics and spatial outcomes from the outside, thereby justifying the construct validity and data reliability of its methods. In this experiment, direct measurements can be obtained through certain "scientific" methods (e.g., surveys). In that kind of economic geography, the firm is objectified as an external monolith, the spatial strategy, action, and outcomes of which are subject to the researcher's investigation "from a distance" - a kind of "remotesensing" approach. On the other hand, new economic geographers do not privilege a dominant voice within and outside the firm. Instead, the contestation and negotiation of this dominant voice and identity becomes an interesting research issue in its own right. To unravel this issue, new economic geographers need to conduct research in situ to obtain much richer and intimate understanding of identities and representations of actors within and outside firms, industries, markets, and regions. In that sense, in situ research offers much more reliability and reflexivity than the remote-sensing approach to studying contemporary economic geographies (see Table 1).

Another methodological implication for practicing new economic geographies is that in situ research tends to improve one's validity in explanations. This point is related to the earlier practice of tracing actor networks. The role of in situ research here is to provide a much deeper understanding of the empirical context through which these actor networks operate. As contextual analysis becomes increasingly important in practicing new economic geographies, "being there" promises not only more reliable data, through direct observations and experiential recording, but also more valid data from observing the subtlety of certain economic processes and the behavior of social actors. A new economic geographer can also be more reflexive of his/her construction of knowledge about the firm under study. In Schoenberger's (1997) research into the cultural dimensions of corporate strategies, she painstakingly spent an enormous amount of time and effort to get close to information sources and key informants in the corporations (see also a reflexive account in Schoenberger 1991). Thus, she was able to 
build a valid and reflexive account of what exactly was going on in these corporations through her in situ research. Had she sent these corporations some general questionnaires and asked whomever responded to evaluate several Likert-styled factors linking corporate culture and strategies (a tactic often found in business and management studies), she would have obtained invalid and, perhaps, unreliable answers to a highly important research question. There is clearly very little reflexivity to talk about in conventional questionnaire surveys that are utilized to test and generalize stylized facts.

A related methodological issue here is that other interested parties can sometimes conduct in situ research on behalf of the researcher, though in a less reflexive manner. I do not refer here to contract researchers or even research assistants. Instead, I am thinking of elites from research houses of stockbroker firms, investment banks, credit-rating agencies, and other institutions (e.g., labor organizations and regulators). These "pseudoresearchers" may have vested interests in unpacking certain firms and corporations. They may also conduct in situ research through personal interviews, focus-group discussion, gossipy talks over lunches and dinners with executives from these corporations, and reading company files and records. Their "expert" reports on and biographies of corporations sometimes contain vast amounts of data obtained through their in situ research. This important source of oral and written data can be profitably exploited by new economic geographers. In brief, in situ research can be a highly valid, reliable, and reflexive methodological practice in new economic geographies.

\section{Generating Theoretical Insights: Abstractions, Deconstructions, and Reconstructions}

As empirical data and information are gathered through in situ research and tracing actor networks, it becomes necessary to return to the "big picture" and generate theoretical insights about economic geographies, whether these insights are explanatory or critical in nature. To make sense out of messy data and information, we regularly construct, deconstruct, and reconstruct theoretical insights. I argue that whatever one's epistemological orientations, he/she should still be concerned with theory development. As Sayer and Storper $(1997,6)$ remark, "Workers may not need Marx to know they are exploited and women may not need feminism to know that they are subordinated, but we are likely to need theory to know how and why these things come about." How, then, should new economic geographers arrive at some sort of theoretical insights, given that their methodological practices as described earlier are rather fluid and open? Here, I argue against the logical deductive approach to theory commonly practiced in neoclassical economic geography. In this mode of "epistemological theorizing" (Barnes 2001b), theory development starts from models, hunches, and hypotheses and ends with verification by empirical data and generalizations. Theories are deducted a priori and tested statistically by empirical data. The causality in these theories does not emerge from careful abstractions based on intensive research methods (see Sayer 1992, 2000; Pratt 1995; Yeung 1997b). Put another way, abstraction as a methodological practice does not occupy an important place in the methodology of neoclassical economic geography because it is neither a valid nor a reliable method for theory development (see Table 1).

For some new economic geographers, abstraction seems to be a more valid practice of theory development. ${ }^{9}$ Abstraction refers to the process through which we abstract "from particular conditions, excluding those which have no significant effect in order to focus on those which do. Even where we are interested in wholes we must select and abstract their constituents" (Sayer 1992, 86). It is a methodological practice "in which the complex, multidimensional nature of objects is progressively disassembled to reveal those connections or relations that explain how objects come into being and are subsequently transformed" (Jones and Hanham 1995, 194). Abstraction serves as a first step towards conceptualizing and theorizing the causal relationships between actors (e.g., firms and their globalization). Abstraction can be a highly valid practice for theorization, since new economic geographers are concerned with the causal interfaces between the "economic" and other spheres of social life (see Table 1). Although the spatial outcomes of these causal interfaces are contingent on the discursive practices of social actors and their action contexts, these interfaces are not readily available to empirical observations. A valid theorization of these interfaces requires an abstraction of their causal effects and putting their causal efficacy into context. Abstraction is used as a methodological practice to specify the necessary relation between the concrete phenomenon (e.g., regional development) and causal structures to form generative mechanisms (e.g., institutions and networks as relational assets). Thus, abstraction remains highly important for practicing new economic geographies.

Not all new economic geographers, however, prefer abstraction as a methodological process for generating theoretical insights. There seems to be an emerging trend in new economic geographies that privileges the deconstruction of grand theories, singular categories, and representations of economic life. Putting its poststructuralist 
philosophical baggage aside (see Barnett 1999), this article examines the methodological implications of deconstruction that aims to "delineate the social power that fixes meanings constructive of identities, spaces, and disciplines" (Dixon and Jones 1998, 255; emphasis omitted). Despite Derrida's claim, in his 1984 work Psyche: Invention of the Other, that deconstruction "does not settle for methodological procedures, it opens up a passageway, it marches ahead and marks a trail" (cited in Lye 1996), the practice of deconstruction is valid and highly reflexive in highlighting the contested and fragmented nature of, say, discursive interpretations of firm's activities and, for that matter, capitalism (see Table 1). It helps us problematize vocabularies, languages, and texts that are used to describe different spheres of socioeconomic life. For example, new vocabularies in management and organizational studies (e.g., competitiveness, competitive advantages, and core competencies) are often internalized within a firm and form the hegemonic norms on the basis of which key corporate decisions are made (e.g., restructuring and laying off staff). The business of business is as much about material processes of economic activities as about talks, conversations, and discourses (Boden 1994; Thrift 1998, 2000a). Some new economic geographers would be interested not only in viewing the firm as an organizational entity capable of producing texts that frame the prevailing rules and power distribution, but also in deciphering the firm as a text for "tracing an infinite spiral of intertextually linked meanings and elisions" (Del Casino et al. 2000, 526). To Barnett (1999, 278, 279), deconstruction is a practice "rigorously parasitic on the corpus of other texts, idioms and traditions ... [Deconstruction] ever works over conceptual systems in particular contexts . . . and implies a different, nonoppositional placement of necessity and contingency, rule and chance, fact and fiction, repetition and change." Its ultimate objective is to engage some form of reflexive criticism. Notwithstanding its ontological and epistemological concerns, deconstruction remains methodologically oriented towards unpacking the discourses and representations of such economic categories as firms, organizations (e.g., labor unions), and institutions (e.g., state economic agencies).

Despite its methodological innovativeness, deconstruction may not be, in its own right, a sufficient practice for theory development. Questions revolve around such issues as what constitutes the beginning and ending of deconstruction and how to know one is really doing deconstruction. While it is able to fulfill our wishes to leave the subject matter unsettled, deconstruction continues to open up spaces for fragmented interpretations by different actors. These, I guess, are what Clark (1998b, 3) means when he ends his article with a caution about "the debilitating effects of fragmented identities and separate royalties." While we should be critical of theoretical categories in neoclassical economic geography-and, indeed, need to deconstruct these categories in order to understand the contexts (intellectual, political, and social) in which these categories are constructed and enforced upon economic geographers-the key methodological challenge remains, "How do we go from there?" Are we satisfied with just leaving everything, as it were, "open" (cf. Dixon and Jones 1998)? We can critically unpack theoretical categories and understand their epistemological constitutions. But this process of deconstruction per se does not go beyond immanent critique and self-reflexivity. Are we happy merely with critical geography's modest aims to "contextualize," "explore," "sketch," "tease out," "trace," "map," "allegoricize," "interrogate," "empathize with," and so on? Insofar as the methodology for new economic geographies is concerned, I believe there is still an urgent need for theory reconstruction through different rounds of abstractions and deconstructions. Through these different rounds of (re)construction, theories are no longer about "stripping" categories out of their contextual richness. On the contrary, this process of theory development involves careful unpacking of contexts and taking a relational approach to present the causality between subjects/ objects. Theory development is not about essentializing theoretical categories; rather, it is about identifying their relational properties and organizing these properties in a meaningful manner.

\section{Towards a Process-Based Methodological Framework for Practicing New Economic Geographies}

The above, necessarily brief examination of various methodological issues demonstrates their inherent bias and weaknesses as stand-alone research practices for new economic geographies. Indeed, Clark (1998b, 83) recognizes this problem when he concludes that "The problem with close dialogue is its lack of cross-referencing with other cases. While it is a powerful strategy for interrogating the claims of stylized facts, it is hardly adequate as a strategy for coalition building [among different scholars and disciplines]." Thus, there seems to be a case for a process-based methodological framework that offers dynamic configurations of research practices for particular research purposes and contexts. In Figure 1, I summarize the relationships among various moments of practicing new economic geographies within my framework, building 


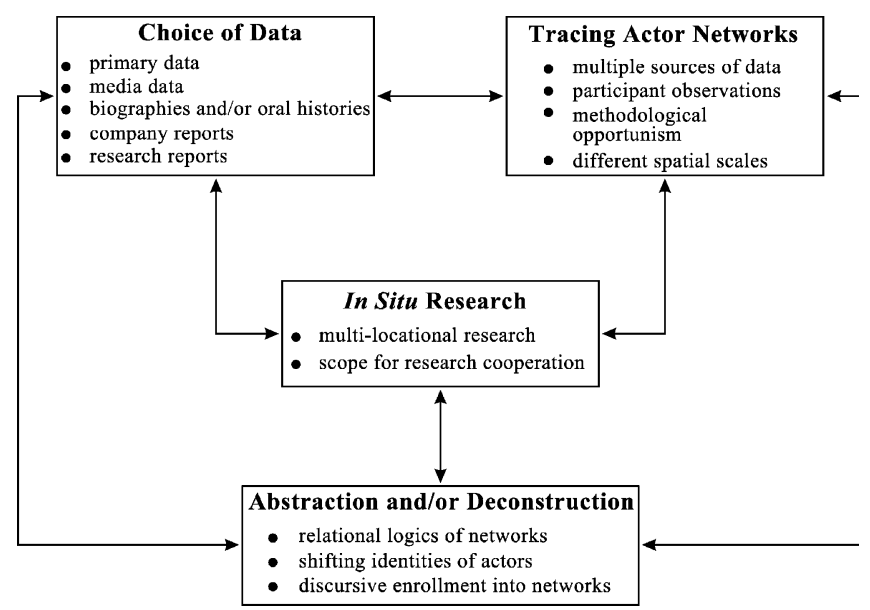

Figure 1. A process-based methodological framework for practicing new economic geographies.

upon some of the materials discussed in the previous section. In Table 2, I lay out explicitly the relationships between substantive issues reviewed earlier and their methodological implications for practicing new economic geographies. I will revisit both Figure 1 and Table 2 again shortly. In this penultimate section, I aim to evaluate the advantages of this process-based methodological framework by paying particular attention to the issues of triangulation and collaborative research possibilities.

In the first place, a process-based methodological framework is better able to overcome the inherent weaknesses of individual stand-alone methods through the process of triangulation, the logic of which rests on the fallibility of any single method or representation of socioeconomic phenomena and psychological constructs. As Denzin $(1989,235)$ argues, different methods are "like the kaleidoscope: Depending on how they are approached, held, and acted toward, different observations will be revealed." Triangulation can also reduce methodological problems associated with eclecticism, because different practices are brought together with a common purpose-triangulating research results and interpretations. Even though some of these methodological practices may appear to be contradictory (e.g., deconstruction versus quantitative methods), their triangulation may offer precisely the kinds of insights and results that go beyond single dominant methodology. Despite its early origin in the practice of social and psychological research (see recent reviews and applications in Scandura and Williams 2000; Risjord, Moloney, and Dunbar 2001; Trosset 2001), however, explicit discussion of triangulation in human geography has so far been minimal, let alone in practicing new economic geographies (see Yeung 1997b, 1998b, 2002b). This relative neglect is explained

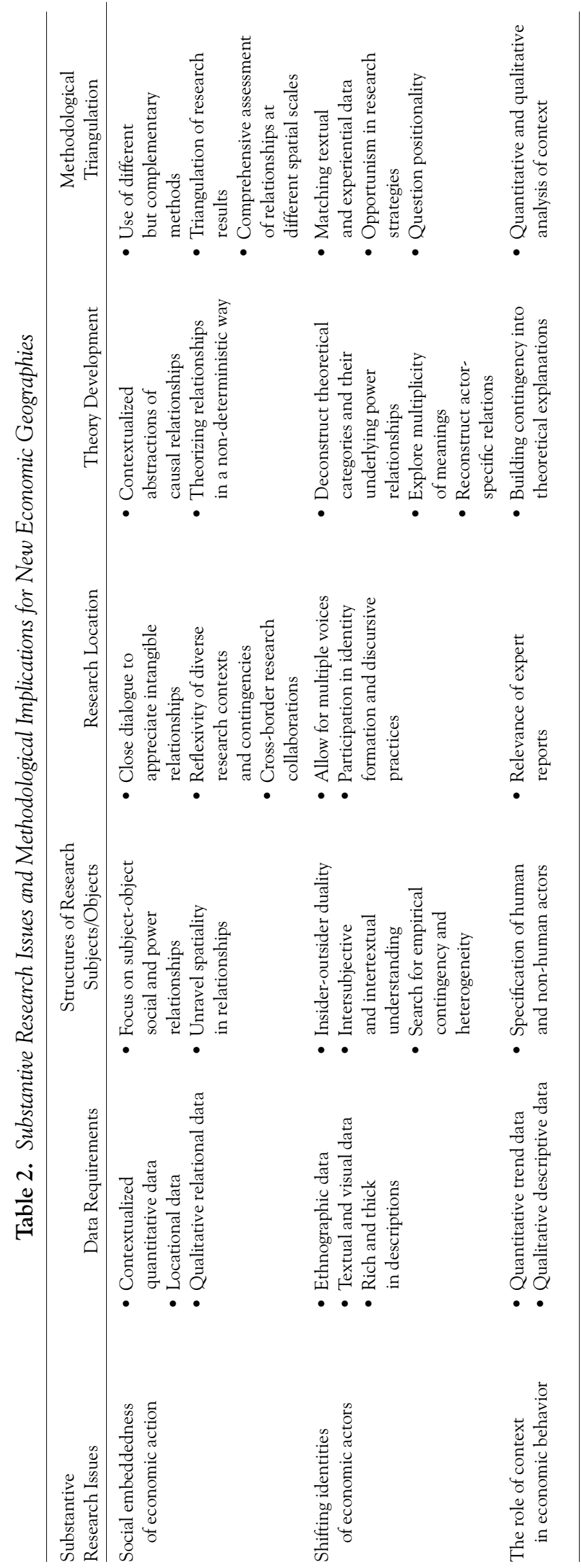


by the general lack of methodological developments, symptomatic of excessive preoccupation with philosophical debates within contemporary human geography. Denzin (1970, chapter 12) suggests four generic forms of triangulation: (1) data triangulation with respect to time, place, person, and level; (2) investigator triangulation among multiple observers of the same phenomenon; (3) theoretical triangulation among multiple theoretical perspectives with respect to the same set of objects; and (4) methodological triangulation through between-method triangulation (dissimilar methods) and within-method triangulation (variations within the same basic methodology). I shall briefly discuss each form of triangulation in relation to my process-based methodological framework.

By implementing data triangulation, different findings in new economic geographies may reveal interesting observations about the various contexts in which data are produced and represented. As shown in Figure 1, new economic geographers can collect data and information from a wide range of sources, including field observations, the media, biographies and oral histories, published reports, and so on. Differences in these data in relation to the phenomenon under investigation (e.g., discursive practices of industrial firms) may offer significant insights into not only the research context, but also the situatedness of the research phenomenon. For example, in investigating the social embeddedness of economic action (see Table 2), the use of different methodological practices to extract and analyze locational, relational, and contextualized data may enable us to better understand how embeddedness can be analyzed at different spatial scales, ranging from social actors (e.g., workers and managers) embedded in local communities to transnational firms embedded in regional economies (e.g., untraded interdependencies). The necessity for data triangulation calls for the abandonment of our traditional dualism in the quantitative-qualitative divide.

Investigator triangulation works in two ways, triangulation of data collection and triangulation of findings/ analyses. While critics of investigator triangulation may argue that no two investigators ever observe the same phenomenon in exactly the same way, I believe that this difference in observations is precisely the strength of investigator triangulation in understanding a complex sociospatial world in which economic action and activities performed by social actors are highly situated and contextualized. In fact, the use of multiple researchers in investigating such phenomena as the discursive practices and multiple identities of economic actors may much better transcend the insider-outsider dualism and may improve reflexivity in research (see Table 2 ). While one researcher on a team may be posed as an outsider (e.g., research into the geographies of finance), another researcher on the same team may have privileged access to the phenomenon under investigation (e.g., actor networks of insider dealings or gendered workplaces). By comparing their findings and/or interpretations, new economic geographers can allow not only for multiple voices by the researchers and their "subjects" (e.g., dealers, managers, and so on), but also for understanding the reflexivity and positionality of their findings. The methodological opportunism available to the insiderresearcher can be analyzed as the research context that differentiates and explains the findings offered by the outsider-researcher. As argued in the earlier section, this concern for reflexivity does not necessarily imply the sacrifice of data/information reliability. Investigator triangulation can indeed increase the reliability of findings, precisely because researchers can account for their different positionalities and research contexts that allow for the successful collection of such data and information. Investigator triangulation also justifies the deployment of cross-national research collaboration, which will be examined later in this section (see Figure 1).

Theoretical triangulation is important for practicing new economic geographies that are influenced by so many different stands of philosophies and/or social theories. It is justified on the ground that one's commitment to a particular philosophy/theory does not forbid an awareness of the multiple insights on the same substantive issues offered by other (competing) philosophies/theories. This form of triangulation for building theories has been referred to as "metatriangulation" by Lewis and Grimes $(1999,676)$, who argue that "Metatriangulation-in-action is highly iterative, as theorists necessarily fluctuate between activities." The key challenge to metatriangulation is the discovery of "transition zones," as boundaries between different philosophies/theories tend to be fuzzy and potentially permeable. In methodological terms, transition zones are gray areas that illustrate differences, similarities, and interrelationships among these philosophies and/or theories. In the context of practicing new economic geographies, theoretical triangulation holds a particular promise to theory development. As argued in earlier sections, while some social theorists prefer destabilizing theoretical categories, others advocate abstractions of causal mechanisms underpinning deep structures. Although it is not possible to force these different and perhaps incommensurable epistemological standpoints into a unified epistemology for research practice, it is at least fair for new economic geographers to explore their disparity and interplay in order to arrive at an enlarged and enlightened understanding of certain substantive issues 
(e.g., in Table 2). Being aware of the strengths and pitfalls of other theoretical frameworks also enhances the likelihood of developing better theoretical insights by new economic geographers.

The above argument clearly points to the critical role of methodological triangulation in practicing new economic geographies (see Figure 1 and Table 2). The use of methodological triangulation as suggested in the processbased methodological framework can achieve convergence validity, in which different methodological practices (e.g., tracing actor networks and in situ research) generate broadly similar and complementary findings. It can also improve the reliability of data and interpretations (e.g., using different data sources). What is necessary in this process of triangulation is to compare and contrast different sources of data/findings if they are addressing the same phenomenon. Alternatively, if different methodological practices are used to investigate different facets of the same phenomenon (e.g., actor networks), the resultant findings tend to be complementary. The methodological implication is that triangulation is useful insofar as different facets of a concrete phenomenon are researched through the most appropriate combination of research practices. It is surely not about replication per se, but about making connections within particular cases. Methodological triangulation also offers an opportunity for reflexive evaluations of the research process that go beyond standard textbook prescriptions of a linear research process. As evident in Figure 1, a process-based methodological framework is explicitly iterative and dynamic, rather than linear and stage-linked (see also endnote 4). In fact, a new economic geographer can start at any moment of the framework (e.g., using deconstruction to open up new spaces and categories for empirical research).

The second and related issue is concerned with the framework's implicit suggestion of collaborative research possibilities. In much of neoclassical economic geography, "armchair" theorizing and "remote sensing" have become the modus operandi for understanding contemporary economic landscapes. This methodological approach clearly runs in contrast to my call for in situ research as an integral moment of the process-based methodological framework (Figure 1). If we view this framework as a knowledge-production chain, I believe that it can be creatively disintegrated through collaborative research across disciplinary and national boundaries. For example, one may not find it possible to trace an actor network in its entirety, particularly those transnational actor networks spanning different countries and/or regions. Collaborative research becomes a useful means to accomplish this task, where researchers from different countries and/or regions engage in joint efforts to trace certain transnational actor networks and their relational properties (e.g., for multilocational research, see Miller et al. 1998; Herod 1999). The use of different methodological practices by these researchers in different locations may also potentially increase the opportunities for investigator and methodological triangulation. The pleasant "research surprises," both theoretical and empirical, that emanate from the diversity of approaches and practices by researchers across borders could be an ideal platform from which to understand multiple representations and shifting identities of social actors. Cross-border research can also provide much information about the social embeddedness of economic activities (see Table 2).

Interdisciplinary research is important here, because actor networks have multifaceted dimensions, manifested in the realms of history, geography, psychology, politics, business, economy, and society. Whereas the execution of the process-based methodological framework may require one to transcend disciplinary and national boundaries, it may also reward an imaginative combination of methodological practices that are inclusive rather than exclusive. Our geographical imaginations can be much enhanced by methodological imagination. As new economic geographies have benefited tremendously from expansive social theories, their methodological practices must similarly be imaginative and expansive. Referring to Table 2 , for example, there is no reason to rule out the usefulness of statistical analyses as a tool for piecing together broad pictures of economic landscapes (see Philo 1998b; Sheppard 2001). What is important for practicing new economic geographies, however, is to bear in mind that results from these analyses provide only a macroview, which leaves detail processes (e.g., social embeddedness of economic action) to other practices and moments within the process-based methodological framework.

\section{Conclusion}

Despite significant theoretical advances in human geography during the past two decades, research methodology has remained underdeveloped. ${ }^{10}$ This underdevelopment is particularly acute in the practice of new economic geographies, where methodology is seriously lagging behind philosophical and theoretical developments, culminating in suspicion and skepticism by other human geographers and social scientists. In this article, I argue that practicing new economic geographies necessarily entails a rethinking of methodological issues. It should be clear by now that I am advocating a more embracing and yet open methodology to practicing new 
economic geographies. The process-based methodological framework developed in this article is embracing, because it transcends methodological dualism in much of social science (e.g., quantitative-qualitative divide); it is open, but not eclectic, because, through triangulation, the framework enables different methodological practices to be deployed to recognize different voices and vocabularies by social actors. These complementary research strategies are not implemented, however, at the expense of methodological validity, reliability, and reflexivity. Indeed, robustness remains a key criterion in assessing data and/or information gathered from these different research practices and their creative combination. While I deny the hegemonic explanatory power of quantitative methodology, I do not believe that it has run its full course yet (cf. Barnes 1996, 1998a; Hepple 1998; Sheppard 2001). In this article, I have taken a revisionist position by showing that while some aspects of quantitative methodology are useful in practicing new economic geographies, we need to think critically about the methodological implications of these new research practices.

In this concluding section, I want to consider briefly two further issues arising from the practice of new economic geographies: (1) contributions to public policy and (2) ethics. Contributions to public policy have always been a hallmark of different varieties of economic geographies and should continue to remain so. Because of their reflexive and pluralistic nature, new economic geographies have better reasons to contribute to public policy (see Tickell 1998). What is the point, for example, of giving multiple voices and representations to social actors if we cannot free them from false consciousness and/ or suppression by dominant hegemonies in organizations, institutions, and localities? It is paradoxical, however, that (new) economic geographers tend to be "studying delivery systems and outcome patterns rather than addressing the fundamentals of policy design and the regulatory "rules of the game' itself" (Peck 1999, 134). This "policy problem," I argue, is particularly disturbing among new economic geographers who are concerned with the social embeddedness of economic action and multiple identities of social actors. While raising our sensitivity to different voices and behavior of social actors, the tendency for some new economic geographies to lean towards open-ended narratives has led to fragmented research and an inability to see the "big picture." This shying away from the "fundamentals" of economic processes among some quarters of new economic geographies is likely to perpetuate this "policy problem" (see also Martin 2001; Martin and Sunley 2001). To sustain the future of new economic geographies, we need to take into account the public-policy agenda in our research. The pro- cess-based methodological framework suggested in this article may well be a first methodological step in producing rigorous new economic geographies that enables geographers to be placed firmly back in diverse policy circles, ranging from international organizations and national governments to local and regional organizations and institutions.

This policy concern by new economic geographies raises another issue about ethics (see also Sayer and Storper 1997). Given the much "deeper" and complex understanding afforded by new economic geographies, we would imagine that policy recommendations by these geographers can potentially be more penetrating in shaping the behavioral and spatial outcomes of social actors. Is it fair and/or ethical, then, for new economic geographers to participate in the lifeworld of social actors for research purposes and yet make use of their findings for policy, which may have an adverse effect on these social actors? Through methodological opportunism, one may get access to an actor network and eventually manage to trace the interconnections of actors in this network through in situ research (see Table 2). The researcher then abstracts some general processes about the economic outcomes of this actor network and makes policy recommendations for government authorities. Assuming this actor network-say, in the financial world-involves a significant degree of greed and corruption in the everyday practice of social actors (see Tickell 1996; Clark 1997, 1998a; Sidaway and Bryson 2002), how does a new economic geographer combine his/her multiple roles as a trusted enrollee of the actor network (for research), an independent critical scholar, and a public citizen with strong civil consciousness? This ethics issue is apparently less significant in neoclassical economic geography, in which the researcher is well separated from the subject of analysis. But for new economic geographers, this issue is an inevitable and integral aspect of the reflexive research process. ${ }^{11}$ Clearly, the ethical challenge to research in new economic geographies can be daunting. A fuller appreciation of this challenge is an important step in our collective intellectual endeavor to develop a comprehensive and methodologically sound research agenda for understanding the full complexity of contemporary economic landscapes and social life.

\section{Acknowledgments}

A much earlier version of this article was presented at the RGS-IBG Annual Conference, Brighton, University of Sussex, 4-7 January 2000, and at research seminars hosted by the National University of Singapore, the 
University of Hong Kong, Copenhagen University, and Uppsala University. I would like to thank participants in these occasions, particularly Bjørn Asheim, Tim Bunnell, Neil Coe, Philip Kelly, George Lin, Anders Malmberg, Ron Martin, Phil Morrison, Kris Olds, and Gunnar Olsson, for their helpful and constructive comments. John Paul Jones III and five anonymous referees of the Annals offered very thoughtful advice that contributed significantly to my revisions of the article. None of these institutions or individuals should be held responsible for any errors or mistakes in this article.

\section{Notes}

1. "New economic geographies" refers to the study of economic activities in relation to other political, social, cultural, and institutional processes in society and space. This literature is clearly different from the emergence of the "new economic geography" in economics that aims to reintroduce spatial analysis into mainstream equilibrium models (Krugman 1998; Ottaviano and Thisse 2001; cf. Martin 1999; Clark, Feldman, and Gertler 2000). My usage of the plural to define new economic geographies is intended to be inclusive rather than exclusive, and to celebrate the multiplicity of approaches to understanding economic geographies today (see also Lee and Wills 1997; Sheppard and Barnes 2000; Barnes 2001b; Lee 2002). In the subsequent section of the article, I outline what is "new" in new economic geographies.

2. Interestingly, several recent articles and journal themed issues have focused on the use of personal interviews and close dialogue in economic geography (Schoenberger 1991, 1994; Clark 1998b; Hughes and Cormode 1998; Cormode and Hughes 1999). Other articles published in the 1980s were exclusively concerned with the role of abstraction and ideology versus statistical generalization (Lever 1985; Massey and Meegan 1985). But the process of research remains fairly underdeveloped in a systematic way in these strands of literature.

3. The word "moment" is used intentionally for two reasons. First, it demonstrates my commitment to a nonlinear and nonsequential way of understanding the research process. In my framework, any moment can be important and prioritized by a particular researcher, depending on the kinds of research questions asked, the theoretical approaches taken, and the research context. Second, and in line with my implicit acceptance of new economic geographies, I want to keep my methodological framework open and dynamic, while also recognizing the complex interrelationships among its constituents.

4. While the use of multimethod research strategy has long received significant attention in social research (Campbell and Fiske 1959; Brewer and Hunter 1989; Brannen 1992; Creswell 1994, 1998), its explicit discussion and application in human geography has not surfaced until very recently (Philip 1998; Graham 1999; McKendrick 1999; Winchester 1999).

5. For an example, we go back to Clark's (1998b) dichotomy of methods in economic geography. While they may be highly reliable because of their replicability, stylized facts tend to be less valid in capturing the complex reality of the economic world. On the other hand, close dialogue may be more valid in "understanding better the actual practice of decision-making [by social actors]" (Clark 1998b, 82). It may, however, encounter serious reliability problems, because the same kinds of data may not be obtainable by another interviewer. See my response to this problem in the next section on triangulation.

6. Philo (1998a, 193) does recognize, however, that quantitative geography contains many different ingredients and should be perceived as a much more complex pursuit, just as "The version of qualitative geography which now sits across the water from quantitative geography is thus a rather different animal." See Dixon and Jones $(1996,768)$ for an elaboration on how scientific geography should not be seen as "a bounded and self-actualizing entity," and Sheppard (2001) for a detailed analysis of the representations, practices, and possibilities of quantitative geography.

7. The theoretical underpinning of actor-network theory draws upon work by Michel Callon, Bruno Latour, and John Law. The theory has gained increasing currency in the social sciences because it is seen "as a useful way of thinking about how spatial relations come to be wrapped up into complex networks" (Murdoch 1999, 357; see also Thrift 1996, 1999b; Olds and Yeung 1999; Hassard, Law, and Lee 1999; Yeung 2000a). It is a useful approach to network research because it offers "a nondualistic standpoint by focusing on how things are 'stitched together' across divisions and distinctions" (Murdoch 1997, 322). The theory's main claim is that actors and their intermediaries from spatially disparate places are enrolled into networks of heterogeneous association and relations. The ability of actors to reach across space and "act from a distance" ultimately depends upon entraining other actors and the necessary material objects, codes, procedural frameworks, and so on required to effect the activation of power. A fundamental part of extended-network construction is the ability to create and manage the knowledge, vocabulary, procedures, rules, and technologies through which economic activity is conducted (e.g., the globalization of accountancy standards or the development of financial reporting). The creation, legitimization, and adoption of such knowledge, rules, and so on generates power for some actors in networks because they are effectively able to reshape the strategy and activities of other actors in networks (see Thrift 1998, 1999b).

8. See England (1994), Gilbert (1994), Katz (1994), Kobayashi (1994), Nast (1994), Staeheli (1994), Staeheli and Lawson (1995), and Jones, Nast, and Roberts (1997) for a discussion of in situ research and representations in feminist geography.

9. The use of abstraction in practicing new economic geographies is certainly not new. The methodological practice has been extensively used in political economy and radical economic geography since the early 1980s (see Sayer 1982, 1992; Massey 1984; Cox and Mair 1989). For reviews of recent geographical research in political economy, see Wills (1999, 2000).

10. Notable recent exceptions include Baxter and Eyles (1997), Bailey, White, and Pain (1999), several journal special issues on the use of focus groups (Area 1996) and quantitative methods (The Professional Geographer 1995; Philo 1998b; Sheppard 2001), researching into elites (Hughes and Cormode 1998; Cormode and Hughes 1999), multimethod 
research in population geography (The Professional Geographer 1999a), and qualitative approaches in health geography (The Professional Geographer 1999b). Physical geographers are also increasingly aware of the issue of methodology in their research practice (see Bauer 1999).

11. A similar issue of ethics is also very relevant to interpretive geographies (Pile 1991; Keith 1992) and feminist geographies (McDowell 1992; England 1994; Kobayashi 1994; Staeheli 1994; Staeheli and Lawson 1995).

\section{References}

Amin, A., and N. Thrift. 2000. What kind of economic theory for what kind of economic geography? Antipode 32:4-9.

Area. 1996. Focus groups. 28:113-49.

Bailey, C., C. White, and R. Pain. 1999. Evaluating qualitative research: dealing with the tension between "science" and "creativity." Area 31:169-78.

Barnes, T. J. 1995. Political economy. Part 1: "The culture, stupid." Progress in Human Geography 19:423-31.

- 1996. Logics of dislocation: Models, metaphors, and meanings of economic space. New York: Guilford.

- 1998a. A history of regression: Actors, networks, machines, and numbers. Environment and Planning $\mathrm{A}$ 30:203-23.

- 1998b. Political economy. Part 3: Confessions of a political economist. Progress in Human Geography 22: 94-104.

-1999. Industrial geography, institutional economics, and Innis. In The new industrial geography: Regions, regulation, and institutions, ed. T. J. Barnes and M. S. Gertler, 1-22. London: Routledge.

- 2001a. Lives lived and lives told: Biographies of the quantitative revolution. Environment and Planning D: Society and Space 19:409-29.

— 2001b. Retheorizing economic geography: From the quantitative revolution to the "cultural turn." Annals of the Association of American Geographers 91:546-65.

Barnett, C. 1998. The cultural turn: Fashion or progress in human geography? Antipode 30:379-94.

- 1999. Deconstructing context: Exposing Derrida. Transactions of the Institute of British Geographers 24:277-93.

Bauer, B. O., ed. 1999. Forum on methodology in physical geography: Current status, implications, and future prospects. Annals of the Association of American Geographers 89:677-778.

Baxter, J., and J. Eyles. 1997. Evaluating qualitative research in social geography: Establishing "rigour" in interview analysis. Transactions of the Institute of British Geographers 22: $505-25$.

England, K. V. L. 1994. Getting personal: Reflexivity, positionality, and feminist research. The Professional Geographer 46:80-89.

Gilbert, M. R. 1994. The politics of location: Doing feminist research at "home." The Professional Geographer 46:90-96.

Graham, E. 1999. Breaking out: The opportunities and challenges of multi-method research in population geography. The Professional Geographer 51:76-89.

Beaverstock, J. V., R. G. Smith, and P. J. Taylor. 2000. World-city network: A new metageography? Annals of the Association of American Geographers 90:123-34.
Boden, D. 1994. The business of talk: Organizations in action. Cambridge, U.K.: Polity.

Brannen, J., ed. 1992. Mixing methods: Qualitative and quantitative research. Aldershot: Avebury.

Brewer, J., and A. Hunter. 1989. Multimethod: A synthesis of styles. Newbury Park, CA: Sage.

Bunnell, T. G. 2002. Multimedia utopia? A geographical critique of high-tech development in Malaysia's multimedia supercorridor. Antipode 34:265-95.

Campbell, D. T., and D. W. Fiske. 1959. Convergent and discriminant validation by the multitrait-multimethod matrix. Psychological Bulletin 56:81-105.

Casetti, E. 1972. Generating models by the expansion method: Applications to geographic research. Geographical Analysis 4:81-91.

Castells, M. 1996. The rise of the network society. Cambridge, MA: Basil Blackwell.

Chapman, K., and H. Edmond. 2001. Abstract databases as information sources in economic geography. Area 33:55-62.

Clark, G. L. 1997. Rogues and regulation in global finance: Maxwell, Leeson, and the city of London. Regional Studies 31:221-36.

- 1998a. The anatomy of corruption: The practice of pension fund trustee decisionmaking. Environment and Planning A 30:1235-53.

. 1998b. Stylized facts and close dialogue: Methodology in economic geography. Annals of the Association of American Geographers 88:73-87.

Clark, G. L., M. A. Feldman, and M. S. Gertler, eds. 2000. The Oxford handbook of economic geography. Oxford: Oxford University Press.

Clark, G. L., and D. Wojcik. 2001. The city of London in the Asian crisis. Journal of Economic Geography 1: $107-30$

Cochrane, A. 1998. Illusions of power: Interviewing local elites. Environment and Planning A 30:2121-32.

Coe, N. M., and P. F. Kelly. 2002. Languages of labour: Representational strategies in Singapore's labour control regime. Political Geography 21:341-71.

Cormode, L., and A. Hughes. 1999. Theme issue on researching elites. Geoforum 30:299-379.

Cox, K., and A. Mair. 1989. Levels of abstraction in locality studies. Antipode 21:121-32.

Creswell, J. W. 1994. Research design: Qualitative and quantitative approaches. London: Sage.

-1998. Qualitative inquiry and research design: Choosing among five traditions. Thousand Oaks, CA: Sage.

Crewe, L. 2000. Geographies of retailing and consumption. Progress in Human Geography 24:295-310.

Del Casino, V. J. Jr., A. J. Grimes, S. P. Hanna, and J. P. Jones. 2000. Methodological frameworks for the geography of organizations. Geoforum 31:523-38.

Denzin, N. K. 1970. The research act in sociology: A theoretical introduction to sociological methods. London: Butterworths.

. 1989. The research act: A theoretical introduction to sociological methods. 3rd ed. London: Prentice Hall.

Dicken, P., P. F. Kelly, K. Olds, and H. W. C. Yeung. 2001. Chains and networks, territories and scales: Towards an analytical framework for the global economy. Global Networks 1:89-112.

Dicken, P., and A. Malmberg. 2001. Firms in territories: A relational perspective. Economic Geography 77:345-63. 
Dicken, P., and N. Thrift. 1992. The organization of production and the production of organization. Transactions, Institute of British Geographer 17:279-91.

Dixon, D. P., and J. P. Jones. 1996. For a supercalifragilisticexpialiidocious scientific geography. Annals of the Association of American Geographers 86:767-79.

Dixon, D. P., and J. P. Jones. 1998. My dinner with Derrida, or spatial analysis and poststructuralism do lunch. Environment and Planning A 30:247-60.

Geertz, C. 1973. The interpretation of cultures. New York: Basic Books.

Gibson-Graham, J. K. 1996. The end of capitalism (as we knew it): A feminist critique of political economy. Oxford: Blackwell.

Glaser, B. G., and A. L. Strauss. 1967. The discovery of grounded theory: Strategies for qualitative research. New York: Aldine.

Granovetter, M. 1985. Economic action and social structure: The problem of embeddedness. American Journal of Sociology 91:481-510.

-. 1991. The social construction of economic institutions. In Socioeconomics: Toward a new synthesis, ed. A. Etzioni and P. R. Lawrence, 75-81. Armonk, NY: M. E. Sharpe.

Granovetter, M., and R. Swedberg eds. 1992. The sociology of economic life. Boulder, CO: Westview Press.

Hammersley, M. 1992. Deconstructing the qualitativequantitative divide. In Mixing methods: Qualitative and quantitative research, ed. J. Brannen, 39-55. Aldershot: Avebury.

- 1999. Taking sides in social research: Partisanship and bias in social enquiry. London: Routledge.

Hanson, S., R. Nagar, L. McDowell, and V. Lawson. 2002. Locating globalization: Feminist (re)readings of the subjects and spaces of globalization. Economic Geography 78 (3): 257-84.

Hassard, J., J. Law, and N. Lee, eds. 1999. Special themed section on actor-network theory and managerialism. Organization 6:387-497.

Hepple, L. 1998. Context, social construction, and statistics: Regression, social science, and human geography. Environment and Planning A 30:225-34.

Henderson, J., P. Dicken, M. Hess, N. M. Coe, and H. W. C. Yeung. 2002. Global production networks and the analysis of economic development. Review of International Political Economy 9 (3): 436-64.

Herod, A. 1999. Reflections on interviewing foreign elites: Praxis, positionality, validity, and the cult of the insider. Geoforum 30:313-27.

Hughes, A., and L. Cormode, eds. 1998. Theme issue: Researching elites and elite spaces. Environment and Planning $A$ 30:2098-180.

Jackson, P. 2002. Commercial cultures: Transcending the cultural and the economic. Progress in Human Geography 26:3-18.

Jones, J. P., and R. Q. Hanham. 1995. Contingency, realism, and the expansion method. Geographical Analysis 27:185-207.

Jones, J. P., H. J. Nast, and S. M. Roberts, eds. 1997. Thresholds in feminist geography: Difference, methodology, representation. Oxford: Rowman and Littlefield.

Katz, C. 1994. Playing the fields: Questions of fieldwork in geography. The Professional Geographer 46:67-72.

Keith, M. 1992. Angry writing: (Re)presenting the unethical world of the ethnographer. Environment and Planning D: Society and Space 10:551-68.
Kelly, P. F. 2001. Metaphors of meltdown: Political representations of economic space in the Asian financial crisis. Environment and Planning D: Society and Space 19:719-42.

Kitchin, R. M., and P. J. Hubbard, eds. 1999. Theme issue on research, action, and "critical" geographies. Area 31: 195-246.

Kobayashi, A. 1994. Coloring the field: Gender, "race," and the politics of fieldwork. The Professional Geographer 46:73-80.

Krugman, P. 1998. What's new about the new economic geography? Oxford Review of Economic Policy 14:7-17.

Lawson, V. A. 1995. The politics of difference: Examining the quantitative/qualitative dualism in poststructuralist feminist research. The Professional Geographer 47:449-57.

Layder, D. 1993. New strategies in social research. Cambridge, U.K.: Polity.

Lee, R. 2002. "Nice maps, shame about the theory"? Thinking geographically about the economic. Progress in Human Geography 26:333-55.

Lee, R., and J. Wills, eds. 1997. Geographies of economies. London: Arnold.

Lever, W. F. 1985. Theory and methodology in industrial geography. In Progress in industrial geography, ed. M. Pacione, 10-39. London: Croom Helm.

Lewis, M., and A. J. Grimes. 1999. Metatriangulation: Building theory from multiple paradigms. Academy of Management Review 24:672-90.

Leyshon, A. 1998. Geographies of money and finance III. Progress in Human Geography 22:433-46.

Lye, J. 1996. Deconstruction: Some assumptions. http://www. brocku.ca/english/courses/4F70/deconstruction.html (last accessed 10 February 2003).

Martin, R. 1999. The new "geographical turn" in economics: Some critical reflections. Cambridge Journal of Economics 23:65-91.

. 2001. Geography and public policy: The case of the missing agenda. Progress in Human Geography 25: $189-210$.

Martin, R., and P. Sunley. 2001. Rethinking the "economic" in economic geography: Broadening our vision or losing our focus? Antipode 33:148-61.

Massey, D. 1984. Spatial division of labour: Social structures and the geography of production. London: Macmillan.

Massey, D., and R. Meegan. 1985. Introduction: The debate. In Politics and method: Contrasting studies in industrial geography, ed. D. Massey and R. Meegan, 1-15. London: Methuen.

McDowell, L. 1992. Doing gender: Feminism, feminists, and research methods in human geography. Transactions of the Institute of British Geographers 17:399-416.

. 1997. Capital culture: Gender at work in the city. Oxford: Blackwell.

McKendrick, J. H. 1999. Multi-method research: An introduction to its application in population geography. The Professional Geographer 51:40-50.

Miller, D., N. J. Thrift, P. Jackson, B. Holbrook, and M. Rowlands. 1998. Shopping, place, and identity. London: Routledge.

Murdoch, J. 1997. Towards a geography of heterogeneous associations. Progress in Human Geography 21:321-37.

. 1999. The spaces of actor-network theory. Geoforum 29:357-74.

Nast, H. J. 1994. Opening remarks on "women in the field." The Professional Geographer 46:54-66. 
Olds, K., and H. W. C. Yeung. 1999. (Re)shaping "Chinese" business networks in a globalising era. Environment and Planning D: Society and Space 17:535-55.

O'Neill, P. M. 2001. Financial narratives of the modern corporation. Journal of Economic Geography 1:181-99.

O’Neill, P. M., and J. K. Gibson-Graham. 1999. Enterprise discourse and executive talk: Stories that destabilize the company. Transactions of the Institute of British Geographers 24:11-22.

Ottaviano, G. I. P., and J.-F. Thisse. 2001. On economic geography in economic theory: Increasing returns and pecuniary externalities. Journal of Economic Geography 1:153-79.

Parry, B. 1998. Hunting the gene-hunters: The role of hybrid networks, status, and chance in conceptualising and accessing "corporate elites." Environment and Planning A 30:2147-62.

Peck, J. A. 1999. Grey geography? Transactions of the Institute of British Geographers 24:131-36.

Peck, J. A., and J. Wills, eds. 2001. Debating economic geography: (More than) responses to Amin and Thrift. Antipode 33:147-227.

Philip, L. J. 1998. Combining quantitative and qualitative approaches to social research in human geography-An impossible mixture? Environment and Planning A 30: 261-76.

Philo, C. 1998a. Reconsidering quantitative geography: The things that count. Environment and Planning A 30:191-201.

_. 1998b. Theme issue: Reconsidering quantitative geography. Environment and Planning A 30:191-332.

Pile, S. 1991. Practising interpretive geography. Transactions of the Institute of British Geographers 16:458-69.

Plummer, P., and E. Sheppard. 2001. Must emancipatory economic geography be qualitative? Antipode 33:194-99.

Plummer, P., E. Sheppard, and R. P. Haining. 1998. Modeling spatial price competition: Marxian versus neoclassical approaches. Annals of the Association of American Geographers 88:575-94.

Plummer, P., and M. Taylor. 2001. Theories of local economic growth. Part 2: Model specification and empirical validation. Environment and Planning A 33:385-98.

Polanyi, K. 1944. The great transformation. New York: Holt, Rinehart.

Pratt, A. C. 1995. Putting critical realism to work: The practical implications for geographical research. Progress in Human Geography 19:61-74.

Pritchard, W. N. 1999. Local and global in cyberspace: The geographical narratives of U.S. food companies on the Internet. Area 31:9-17.

The Professional Geographer. 1995. Forum: Should women count? The role of quantitative methodology in feminist geographic research. 47:426-66.

-1999a. Focus: Multi-method research in population geography. 51:40-89.

—. 1999b. Focus: Qualitative approaches in health geography. 51:240-320.

Risjord, M., M. Moloney, and S. Dunbar. 2001. Methodological triangulation in nursing research. Philosophy of the Social Sciences 31:40-59.

Rose, G. 1997. Situated knowledges: Positionality, reflexivities, and other tactics. Progress in Human Geography 21:305-20.

Sabot, E. C. 1999. Dr. Jekl, Mr. H(i)de: The contrasting face of elites at interview. Geoforum 30:329-35.
Sayer, A. 1982. Explanation in economic geography: Abstraction versus generalization. Progress in Human Geography 6:68-88.

. 1992. Method in social science: A realist approach. London: Routledge.

-2000. Realism and social science. London: Sage.

Sayer, A., and M. Storper. 1997. Ethics unbound: For a normative turn in social theory. Environment and Planning D: Society and Space 15:1-17.

Scandura, T. A., and E. A. Williams. 2000. Research methodology in management: Current practices, trends, and implications for future research. Academy of Management Journal 43:1248-64.

Schoenberger, E. 1991. The corporate interviews as a research method in economic geography. The Professional Geographer 43:180-89.

- 1994. Corporate strategy and corporate strategists: Power, identity, and knowledge within the firm. Environment and Planning A 26:435-51.

- 1997. The cultural crisis of the firm. Oxford: Basil Blackwell.

. 1998. Discourse and practice in human geography. Progress in Human Geography 22:1-14.

Scott, A. J. 2000. Economic geography: The great half-century. Cambridge Journal of Economics 24:483-504.

Sheppard, E. 2001. Quantitative geography: Representations, practices, and possibilities. Environment and Planning D: Society and Space 20:535-54.

Sheppard, E., and T. J. Barnes, eds. 2000. A companion to economic geography. Oxford: Blackwell.

Sidaway, J. D., and J. R. Bryson. 2002. Constructing knowledges of "emerging markets." Environment and Planning A 34:401-16.

Silverman, D. 1993. Interpreting qualitative data: Methods for analysing talk, text, and interaction. London: Sage.

Staeheli, L. A. 1994. A discussion of "women in the field": The politics of feminist fieldwork. The Professional Geographer 46:96-102.

Staeheli, L. A., and V. A. Lawson. 1995. Feminism, praxis, and human geography. Geographical Analysis 27:321-38.

Sunley, P. 1996. Context in economic geography: The relevance of pragmatism. Progress in Human Geography 20:338-55.

Taylor, M., and B. T. Asheim. 2001. The concept of the firm in economic geography. Economic Geography 77:315-28.

Thrift, N. 1996. Spatial formations. London: Sage.

- 1998. The rise of soft capitalism. In An unruly world: Globalization, governance, and geography, ed. A. Herod, G. ÓTuathail, and S. M. Roberts, 25-71. London: Routledge.

- 1999a. The globalisation of business knowledge. In Globalisation and the Asia Pacific: Contested territories, ed. K. Olds, P. Dicken, P. Kelly, L. Kong, and H. W. C. Yeung, 57-71. London: Routledge.

- 1999b. The place of complexity. Theory, Culture and Society 16:31-69.

. 2000a. Pandora's box? Cultural geographies of economies. In The Oxford handbook of economic geography, ed. G. L. Clark, M. A. Feldman, and M. S. Gertler, 689-704. Oxford: Oxford University Press.

. 2000b. Performing cultures in the new economy. Annals of the Association of American Geographers 90: 674-92. 
Thrift, N., F. Driver, and D. Livingstone. 1995. The geography of truth. Environment and Planning D: Society and Space 13:1-3.

Thrift, N., and K. Olds. 1996. Refiguring the economic in economic geography. Progress in Human Geography 20: 311-37.

Tickell, A. T. 1996. Making a melodrama out of a crisis: Reinterpreting the collapse of Barings Bank. Environment and Planning D: Society and Space 14:5-33.

- 1998. On critical geography and civil society. Environment and Planning A 30:761-66.

Trosset, C. 2001. Triangulation and confirmation in the study of Welsh concepts of personhood. Journal of Anthropological Research 57:61-81.

Walters, W. 1999. De-centering the economy. Economy and Society 28:312-23.

Ward, K. G., and M. Jones. 1999. Researching local elites: Reflexivity, "situatedness," and political-temporal contingency. Geoforum 30:301-12.

Wills, J. 1999. Political economy. Part 1: Global crisis, learning, and labour. Progress in Human Geography 23:443-51.

. 2000. Political economy. Part 2: The politics and geography of capitalism. Progress in Human Geography 24:641-52.

Wills, J., and R. Lee. 1997. Introduction. In Geographies of economies, ed. R. Lee, xv-xviii. London: Arnold.

Winchester, H. P. M. 1999. Interviews and questionnaires as mixed methods in population geography: The case of lone fathers in Newcastle, Australia. The Professional Geographer 51:60-67.

Yeung, H. W. C. 1994. Critical reviews of geographical perspectives on business organisations and the organisation of production: Towards a network approach. Progress in Human Geography 18:460-90.

- 1997a. Business networks and transnational corporations: A study of Hong Kong firms in the ASEAN region. Economic Geography 73:1-25. 1997b. Critical realism and realist research in human geography: A method or a philosophy in search of a method? Progress in Human Geography 21:51-74.

. 1998a. Capital, state, and space: Contesting the borderless world. Transactions of the Institute of British Geographers 23:291-309.

-.1998b. Transnational corporations and business networks. London: Routledge.

. 2000a. The dynamics of Asian business systems in a globalising era. Review of International Political Economy 7:399-433. . 2000b. Organising "the firm" in industrial geography. Part 1: Networks, institutions, and regional development. Progress in Human Geography 24:301-15.

- 2000c. Reconceptualising the "firm" in new economic geographies: An organisational perspective. Paper presented at workshop "The Firm" in Economic Geography, 9-11 March, University of Portsmouth, U.K., Copy available from author.

. 2001a. Does economics matter for/in economic geography? Antipode 33:168-75.

. 2001b. Regulating "the firm" and sociocultural practices in industrial geography. Part 2. Progress in Human Geography 25:293-302.

. 2002a. Doing what kind of economic geography? Journal of Economic Geography 2:250-52.

. 2002b. Entrepreneurship and the internationalisation of Asian firms: An institutional perspective. Cheltenham: Edward Elgar.

-2002c. The limits to globalization theory: A geographic perspective on global economic change. Economic Geography 78:285-305.

- 2002d. Towards a relational economic geography: Old wine in new bottles? Paper presented at the 98th Annual Meeting of the Association of American Geographers, 19-23 March. Los Angeles (Copy available from author.) 